\title{
Analysis of patent registries in Brazilian nursing and its relationship with the professional master's degree
}

\author{
Análise dos registros de patentes na enfermagem brasileira \\ e sua relação com o mestrado profissional \\ Análisis de registros de patentes en enfermería brasileña \\ y su relación con el máster professional
}

\section{Cláudio José de Souza ${ }^{a}$ \\ Zenith Rosa Silvino ${ }^{a}$ \\ Deise Ferreira de Souza ${ }^{a}$}

\section{How to cite this article:}

Souza CJ, Silvino ZR, Souza DF. Analysis of patent registries in Brazilian nursing and its relationship with the professional master's degree. Rev Gaúcha Enferm. 2020;41:e20190358. doi: https://doi. org/10.1590/1983-1447.2020.20190358 a Universidade Federal Fluminense (UFF), Faculdade de Enfermagem Aurora de Afonso Costa. Niterói, Rio de Janeiro, Brasil.

\section{ABSTRACT}

Objective: To analyze the patent registrations registered in the nursing area from 2004 to 2019, relating to the beginning of the Professional Masters in Nursing.

Method: Electronic documentary research carried out at the bases of the National Institute of Industrial Property and Lattes Platform. After data collection, requests, filing date, patent titles, international patent classification and areas of expertise of depositor / inventors were analyzed.

Results: The study points out that there was no significant correlation between the number of registered patents with the prelude to the professional master's degree in nursing, corroborating with previous studies regarding incipience

Final considerations: although two of the initial objectives of professional master's programs are creation and technological innovation, it is analyzed that the granted institutions need to simplify and equip researchers with regard to the patent registration process, so that we can take off in this technological universe.

Keywords: Education, nursing, graduate. Education, professional. Biomedical technology. Patent.

\section{RESUMO}

Objetivo: Analisar os registros de patentes registradas na área da enfermagem no período de 2004 a 2019, relacionando com o início dos Mestrados Profissionais em Enfermagem.

Método: Pesquisa documental eletrônica realizada nas bases do Instituto Nacional da Propriedade Industrial e Plataforma Lattes. Após coleta dos dados foram analisados os pedidos, a data de depósito, os títulos da patente, a classificação internacional de patentes e as áreas de atuação dos profissionais depositantes/inventores.

Resultados: 0 estudo aponta que, não houve uma correlação significativa entre os números de patentes registradas com o prelúdio do mestrado profissional em Enfermagem, corroborando com estudos anteriores quanto à incipiência.

Considerações finais: Apesar de serem dois dos objetivos iniciais dos programas de mestrados profissionais a criação e a inovação tecnológica, analisa-se que as instituições outorgadas precisam simplificar e instrumentalizar os pesquisadores quanto ao processo de registros de patentes, para que possamos deslanchar neste universo tecnológico.

Palavras-chave: Educação de Pós-Graduação em Enfermagem. Educação profissionalizante. Tecnologia biomédica. Patente.

\section{RESUMEN}

Objetivo: Analizar los registros de patentes registrados en el área de enfermería de 2004 a 2019, en relación con el inicio de la Maestría Profesional en Enfermería.

Method: Investigación documental electrónica realizada en las bases del Instituto Nacional de Propiedad Industrial y Plataforma Lattes. Después de la recopilación de datos, se analizaron las solicitudes, la fecha de presentación, los títulos de patentes, la clasificación internacional de patentes y las áreas de actividad de los depositantes / inventores.

Resultados: El estudio señala que no hubo una correlación significativa entre el número de patentes registradas con el preludio al título de maestría profesional en enfermería, lo que corrobora con estudios previos sobre incipiencia.

Consideraciones finales: Si bien dos de los objetivos iniciales de los programas de maestría profesional son la creación y la innovación tecnológica, se analiza que las instituciones otorgadas deben simplificar y equipar a los investigadores con respecto al proceso de registro de patentes, para que podamos despegar en este universo tecnológico.

Palabras clave: Educación de postgrado en enfermería. Educación profesional. Tecnología biomédica. Patente. 


\section{口INTRODUCTION}

Technique and technology have followed man since prehistoric times, when the first primates built tools to hunt and survive due to their basic human survival needs. It is not surprising that throughout its evolutionary process, the human race used these attributes at different times and stages of its evolution. In this sense, it can be explained that technique is the way in which men use their mental faculty to reflect on a certain phenomenon - a problem, and technology is the practical application of this thought, with the objective of solving such questions, either through processes and/or products ${ }^{(1)}$.

Based on this concept, mankind was able to transcend obstacles in each stage, boosted by a feeling of curiosity and constant challenge that made them different from other animals, as they are imbued with rationality and intentionality in practically everything they do. Over these two millennia of existence, specifically in the 18th and 19th centuries, this ability to transform the world's reality culminated in the Industrial Revolution process, with man leading a series of creations and technological innovations in favor of improving quality of life, and the rise of societies ${ }^{(2)}$.

In parallel to this context, modern Nursing emerges at the end of the 19th century, and with it, the entire transcendental process of the evolution of any human group. Thus, through the experiences of its precursor Florence Nightingale, Nursing has transcended over the years, adding the virtue of creating, innovating and, at times, adapting to the profile of its professionals, thus contributing to the area of Health Sciences for the growth and improvement of technologies in the scope of health and nursing.

As nursing consolidates itself as a given science, there is a need to scientificize the profession through research. In Brazil, this Graduate milestone culminates with the publication of the Sucupira Opinion in 1965, which, in its outline, points to the implementation of the two types of stricto sensu courses: academic and professional. However, in the 1970s, perhaps due to the need for a qualified body of professionals to expand teaching, those responsible for implementing the program opted for the academic modality, whose initial objective was to increase the number of masters, especially in the southeast region ${ }^{(3)}$.

As Brazilian nursing is a dynamic profession and has been adapting to the context in which it is inserted, 1995 saw the advent of the Brazilian Postgraduate Policy, instituted by the Higher Council of the Coordination for the Improvement of Higher Education Personnel (Capes), in order to rescue and meet the demands already mentioned in the Sucupira Opinion. Thus, this policy made it possible to encourage discussions about the need to implement professional master's courses. According to the records, this modality was implemented in Brazil in the 1990s under the name "professional master's degree", and regulated by Ordinance no.17, of December 28, 2009, which provides for the professional master's degree within the scope of Capes and, more recently, by Ordinance no.389, of March 23, 2017, which revokes the prior and provides for professional Master's and Doctorate degrees within the scope of the Brazilian stricto sensu graduate program ${ }^{(4)}$.

The first Brazilian course in the field of nursing, within the modality of Professional Master's courses, focused on the area of Obstetrics, having started in 2001 at the Federal University of São Paulo (Unifesp), which offered only one class and titled four masters, ending its academic activities in 2004, when the last master's student defended her dissertation. Thus, it can be considered that the Professional Master's Degree in Nursing Assistance (MPEA), from the Aurora de Afonso Costa Nursing School (EEAAC) of the Universidade Federal Fluminense (UFF), is the first course in uninterrupted activities, having started its academic activities in 2002, maintaining them to the present day. Throughout its eighteen years of operation, the program pledged to instill the development of social responsibility through the realization of a professional nursing practice based on scientific evidence, and invoke a need to transform the problems encountered in daily life into objects of study ${ }^{(5)}$. These are the program's main objectives for these professionals.

Due to human nature, mankind is endowed with singularities, where the concepts of technique and technology intertwine. However, not all human beings are accustomed to using them in a scientific way and, when they do, for the most part, it occurs mechanically. In nursing it is not very different. However, this does not prevent those who are in a constant movement to think critically about their daily tasks and reflect their professional practice differently, thus seeking to improve the service through processes and products. This movement meets the process of innovation and creativity, a result that is expected from a professional who is studying the stricto-sensu - professional modality ${ }^{(6)}$.

In Brazil, the body responsible for registering and granting Trademarks, Patents, Industrial Design, Technology Transfer, Geographical Indication, Computer Program and Integrated Circuit Topography is the National Institute of Industrial Property (INPI), considered an autonomous, auxiliary entity that is decentralized from public administration, linked to the Ministry of Development, Industry and Foreign Trade (MDIC), located in the city of Rio de Janeiro(7).

Law no. 9.2799, of May 14, 1996 (Industrial Property Law), in its art.9, clarifies important points for those who intend to 
patent their products, stating that: "The object of practical use, or a part of it susceptible to industrial application, which presents a new form or arrangement, involving an inventive act, resulting in a functional improvement in its use or in its manufacture, is patentable as a utility model'(7:3). In addition, on a national level, the INPI aims to regulate the rules of Industrial Properties within the social, economic, legal and technical context. Moreover, it is also responsible for supervising the processes related to registrations, especially with regard to the convenience of signatures, denouncing conventions, treaties, covenants and agreements on industrial property ${ }^{(8)}$.

Thus, from the fruitful scenario for possible patent registrations that is the professional masters of nursing, the following guiding question emerged for this research: is there a relationship between the increase in patent registrations in nursing and the emergence of professional master's programs? As a result of this question, this study intended to analyze the nursing patent registry requests related to the beginning of the Professional Nursing Master's programs submitted between 2004 and 2019.

\section{METHODS}

This study is an electronic, descriptive, retrospective documentary research with a quantitative approach. The scientific method used focuses on the appropriation of documents that have not undergone an analytical approach, or that may still undergo a reframing according to the objectives proposed by the research. Accessibility to documentary collections electronically, in the case of patent registrations, allows the public of interest - professional area - to follow up, as it allows professionals to follow up on the possible products/processes produced by their colleagues ${ }^{(9)}$.

Data were collected from May to August 2019, using the following sources:

a) INPI patent registration database ${ }^{(8)}$, with the objective of locating all patent applications filed in the period from 2004 to 2019, a time frame that culminates with the first class of the Professional Master's in Nursing, from UFEA's EEAAC. For this search, five search strategies were used offered by the registration database of the INPI website. The first was through the search for nursing patents by title. Five records were found, of which only two were within the proposed time frame. The second search was by summary, with a result of forty-five records, and, according to the proposed time frame (2004-2019), only twenty-eight records met the criteria. The third, fourth and fifth searches were also done by summary, with the inclusion of the name of the depositor, name of the inventor and CPF/CNPJ of the depositor, respectively, but they did not show any records. It is worth mentioning that the two records found in the first search were found in the second search, therefore, it was preferred to use the records found in the latter. The information obtained in the INPI database was correlated with the search for the names of inventors in the Lattes Platform to obtain data related to academic/professional training.

b) Lattes Platform ${ }^{(10)}$ - when selecting the search for lattes curriculum, we searched for "patents" as the "Subject (Title or production keyword)" search mode, "Professional performance" filter, selecting "Health Sciences" in "Greater Fields" and "Nursing" in "Field". The system returned forty-four patent filings.

After locating this data both at the INPI base and at the Lattes Platform, a table was created containing the following items: order records; filing date; patent title; international classification of patents and area of expertise of the inventor.

As this is research is one in which the materials collected are in the public domain and do not need direct involvement with human beings during the collection, there was no need for approval by the Research Ethics Committee, and indication by the National Health Council.

\section{RESULTS AND DISCUSSION}

The research at INPI was developed based on a previously established protocol that allowed the selection of fifty patent applications, however, considering the search strategy by summary, forty-five records were found, and when using the time frame from 2004 to 2019, only twenty-eight orders were selected, which are shown in Chart 1.

Registration requests were distributed as follows: 2 (7\%) in 2004, 1 (3.5\%) in 2005, 2 (7\%) in 2006, $3(11 \%)$ in 2007, 3 $(11 \%)$ in 2008, $1(3.5 \%)$ in 2009, 1 (3.5\%) in 2010, 2 (7\%) in $2011,3(11 \%)$ in $2011,6(21 \%)$ in 2015, 1 (3.5\%) in 2016, and 3 (11\%) in 2017. Withing this interval, the year 2015 presented the largest number of patent registration requests.

Regarding the expertise of professionals who applied for patent registration, a double check was carried out both on the data from the INPI platform and on the Lattes Platform. In 2004, the two requests were filed by nurses, one with an academic Master's degree, and the other was not found when accessing the Lattes Platform. In 2005, the request was filed by a production engineer; in 2006 by a nurse with a doctorate and a pharmacist.

Of the three requests filed in 2007, one was submitted by a nurse, and the other two were not found on the Lattes Platform. In 2008, two were submitted by a production engineering and one by a nurse. In 2009, the single submission was not found when accessing the Lattes Platform. In 2010, one request was submitted by a nurse with an academic 
master's degree. In 2011, one was submitted by a registered nurse with an academic master's degree, and one was not found when accessing the Lattes platform. In 2012, one was a physiotherapist, one was a nurse with a PhD degree, but had previously done a Professional Master's in Production Engineering, and one was not found when accessing the Lattes platform. In 2015, one request was submitted by a lawyer, and the remaining four were not found when accessing the Lattes platform. In 2016, one was submitted by a nurse with a professional Master's degree in production engineering and in 2017, one was a nurse with a doctoral degree, and the other was an Information System graduate with a doctorate in engineering.

Of the twenty-eight patent registrations in the INPI database, ten were requested by nurses and, of these, only two had a Professional Master's degree. However, in the field of Production Engineering; four were requested by production engineering professionals, while the others were submitted by a lawyer, a physiotherapist, and a pharmacist respectively. It was not possible to determine the professional fields of the other eleven at the INPI bases nor the Lattes Platform, since the curricula were not found.

The research on the Lattes Platform was developed based on a previously established protocol, as described in the method, allowing the selection of forty-four people. However, considering the 2004 to 2019 time frame, only three nurses were located in Lattes, in which they had more than one registered patent. In order to verify this information, the INPI database was accessed again, and the basic search for a patent was carried out with the search key "contain all words" in the title. The results are shown in Chart 2:

According to information crossed, that is, of the records in the Lattes Curriculum, with the INPI base, it can be identified that: of the five records of the nurse ', only four can be found at the INPI, while for nurses "I-II, none of the records can be found by crossing the information from the Lattes curriculum records with the INPI database, using both the application number and the patent title as search criteria.

The study "Brazilian technological production in the field of nursing: advances and challenges" of 2011, corroborates that the advent of the Professional Master's Degree in Nursing did not contribute to the increase in the registration of patents here in Brazil. The authors affirm that Brazil is a country that is still moving timidly regarding the incentive and promotion of patent development and registration, mainly in the area of Nursing, despite the significant increase in the processes and products of these programs, especially with regard to light and hard light technologies. However, these productions are still not properly registered and patented ${ }^{(2)}$.
In another study, entitled "Evaluation of scientific production, patents and human resource training in Brazilian Nursing", published in 2015, the authors verified a number of significant productions among Nursing researchers, especially those that are considered vehicles of scientific information such as: scientific articles, books and book chapters. However, both the production and the registration of technological processes and products (patents) are still incipient taking into account the number of programs accredited by Capes ${ }^{(11)}$.

With regard to the classification of technical production in the Nursing field, in the document made available by Capes ${ }^{(11)}$, the products that could possibly generate patents are: computational application, multimedia and other computer programs, with application development being its subtype; development of a patentable product/process, its subtype being apparatus, instrument, equipment, drugs and generics and others, and brands; development of technique, being its subtype analytical, instrumental, pedagogical, procedural, therapeutic and others, and experimental technological protocol/application or technological adaptation; development of didactic and instructional material, its subtype being technical books, educational materials - games, manuals, booklets, articles in technical bulletins and magazines, instructional educational material with multimedia and educational portal; development of social technology, its subtype being transformative techniques and methodologies; development of unpatentable process/ technology, unpatentable product or process/technology and management processes.

According to the four-year evaluation of Brazilian graduate programs between 2013 and 2016, technological productions, both in terms of processes and products, developed in the Nursing field, are still presented in incipient numbers, with these impacts remaining at the level local and regional in their majority. Still according to the four-year evaluation, the stricto sensu modality of professional master's is recent, with only eighteen years in age compared to the oldest program. The Professional Master's Degree in Nursing Assistance (MPEA-UFF) is still, as in several areas, establishing its specificities, especially regarding expertise in technological production and innovation ${ }^{(12)}$.

The study entitled "Considerations on the evaluation process of Capes Graduate Studies: Contribution of the Brazilian Academy of Sciences", from 2018, already points to a concern about technological innovations in the stricto sensu graduate programs. However, it is analyzed that the main fields of knowledge that contribute for Brazil to occupy a prominent place are the Exact Sciences and not the Health Sciences, including Nursing. Furthermore, in this same report, the authors point out the need for evaluation 


\begin{tabular}{|c|c|c|c|c|}
\hline Order & Deposit & Patent Title & IPC & $\begin{array}{l}\text { Professional } \\
\text { field }\end{array}$ \\
\hline $\begin{array}{c}\text { BR } 202017 \\
0265515\end{array}$ & $12 / 8 / 2017$ & $\begin{array}{l}\text { Device for safe transportation of the newborn in a } \\
\text { hospital environment }\end{array}$ & A47D 13/02 & Nurse \\
\hline $\begin{array}{c}\text { BR } 102017 \\
0262375\end{array}$ & $12 / 5 / 2017$ & $\begin{array}{l}\text { Mobile device to assist health professional procedures } \\
\text { and its method of use }\end{array}$ & $\begin{array}{l}\text { G06F 19/00 } \\
\text { Changed to } \\
\text { G16C } 10 / 00\end{array}$ & Production engineer \\
\hline $\begin{array}{c}\text { BR } 202017 \\
0115548\end{array}$ & $5 / 26 / 2017$ & Mechanism for moving hospital stretcher segment & $\mathrm{A} 61 \mathrm{G} 7 / 14$ & Not found \\
\hline $\begin{array}{c}\text { BR } 102016 \\
0255848\end{array}$ & $11 / 1 / 2016$ & Arm simulator device for injecting procedures & G09B 23/30 & $\begin{array}{l}\text { Nurse/Professional Master's in } \\
\text { Production Engineering }\end{array}$ \\
\hline $\begin{array}{c}\text { BR } 102015 \\
0286708\end{array}$ & $11 / 16 / 2015$ & Multifunctional device for intravascular line & A61M 5/14 & Not found \\
\hline $\begin{array}{c}\text { BR } 102015 \\
0241402\end{array}$ & $9 / 18 / 2015$ & $\begin{array}{l}\text { High-complexity interdisciplinary patient } \\
\text { management system }\end{array}$ & G06Q10/06 & Not found \\
\hline $\begin{array}{c}\text { BR } 102015 \\
0216530\end{array}$ & $9 / 4 / 2015$ & Digital hospital call system & $\mathrm{G} 16 \mathrm{H} \mathrm{40/20}$ & Not found \\
\hline $\begin{array}{c}\text { BR } 202015 \\
0214451\end{array}$ & $9 / 3 / 2015$ & Disposition applied to diapers for premature newborns & A61F 13/15 & Not found \\
\hline $\begin{array}{c}\text { BR } 102015 \\
0083386\end{array}$ & $4 / 14 / 2015$ & Injury treatment apparatus, process, kit and procedure & A61F 13/02 & Not found \\
\hline $\begin{array}{c}\text { BR } 102012 \\
0281120\end{array}$ & $11 / 1 / 2012$ & $\begin{array}{l}\text { Authorizing system for medical procedures using } \\
\text { artificial intelligence }\end{array}$ & G06Q 50/22 & Not found \\
\hline $\begin{array}{c}\text { BR } 102012 \\
0220571\end{array}$ & $8 / 31 / 2012$ & $\begin{array}{l}\text { Didactic kit for the process of obtaining the placebo vial } \\
(\mathrm{PV}) \text { and for practicing the technique of preparing similar } \\
\text { substances to medication presented in vial }\end{array}$ & A61 J 1/06 & $\begin{array}{l}\text { Nurse/Professional Master's degree } \\
\text { in Production Engineering }\end{array}$ \\
\hline $\begin{array}{c}\text { BR } 102012 \\
0056364\end{array}$ & $3 / 14 / 2012$ & Automatic ankle mobilizer & A61H 1/02 & Physiotherapist \\
\hline MU 9102202-9 & $11 / 11 / 2011$ & Computerized educational board game for nursing & A63F3/00 & Nurse \\
\hline
\end{tabular}

Chart 1 - Synopsis of patent application processes registered at the INPI Patent Bank with their respective application records, filing date, patent title, international patent classification and the inventor's area of expertise. Brazil 2004-2019. 


\begin{tabular}{|c|c|c|c|c|}
\hline Order & Deposit & Patent Title & IPC & $\begin{array}{l}\text { Professional } \\
\text { field }\end{array}$ \\
\hline PI 1103701-6 & $7 / 29 / 2011$ & Modular kit for assembling hospital furniture and others & A47B 87/00 & Not found \\
\hline PI 1004066-8 & 10/18/2010 & Bedridden patient hygiene equipment system & $\mathrm{A} 61 \mathrm{H} 33 / 00$ & Nurse \\
\hline MU 8902717-5 & 10/13/2009 & Bedridden patient hygiene equipment & A61G 9/00 & Not found \\
\hline PI 0805382-0 & $12 / 2 / 2008$ & Hospital support for bedridden patients & A61G 1/06 & Nurse \\
\hline MU 8803186-1 & $12 / 1 / 2008$ & $\begin{array}{l}\text { Constructive provision introduced in connector device } \\
\text { for parenteral solution bag }\end{array}$ & A61M 5/32 & Production engineer \\
\hline PI 0806000-2 & $10 / 29 / 2008$ & $\begin{array}{l}\text { Structural configuration applied in bed for placement of } \\
\text { peripherals for computerization of bed }\end{array}$ & A61N 5/06 & Production engineer \\
\hline PI 0715019-9 & 9/18/2007 & Heat preservative sanitary nursing bed & A61G 7/00 & Not found \\
\hline MU 8702609-0 & $6 / 1 / 2007$ & Restriction glove & A41D 19/015 & Nurse \\
\hline PI 0701041-9 & $4 / 13 / 2007$ & $\begin{array}{l}\text { Hand or foot controlled aerosol production system } \\
\text { and devices }\end{array}$ & A61M 11/00 & Not found \\
\hline PI 0603740-2 & $9 / 12 / 2006$ & Portable shower for bed bath & $\mathrm{A} 61 \mathrm{H} 33 / 00$ & Nurse \\
\hline PI 0616536-2 & $7 / 21 / 2006$ & $\begin{array}{l}\text { Use of a hydroxy benzoic acid ester and its analogs in } \\
\text { the manufacture of a medicine for the prevention and } \\
\text { treatment of virus infection }\end{array}$ & A61K $31 / 215$ & Pharmaceutical \\
\hline PI 0504656-4 & $10 / 17 / 2005$ & Swallowable enteral tube and its method of use & A61B 1/273 & Production engineer \\
\hline MU 8402305-8 & $9 / 24 / 2004$ & Disposable orotracheal cannula fixator & A61M 16/04 & Nurse \\
\hline PI 0401713-7 & $5 / 7 / 2004$ & $\begin{array}{l}\text { Composition of papain associated with magnesium } \\
\text { silicate for wound healing }\end{array}$ & A61K 38/48 & Nurse \\
\hline
\end{tabular}

Chart 1 - Cont

Source: Patent Registry Bank of the National Institute of Industrial Property (INP), 2019. 


\begin{tabular}{|c|c|c|c|c|}
\hline Order & Deposit & Patent Title & IPC & Professional Field \\
\hline BR10201807274 & $11 / 5 / 2018$ & $\begin{array}{l}\text { Formulation for the combined use of [10]-gingerol (10G) } \\
\text { with doxorubicin (DOXO) for the treatment of triple } \\
\text { negative breast cancer (TNBC) }\end{array}$ & $\begin{array}{l}\text { Not } \\
\text { found }\end{array}$ & Nurse' \\
\hline $\begin{array}{l}\text { BR } 102016 \\
0181500\end{array}$ & $8 / 4 / 2016$ & $\begin{array}{l}\text { ADAM10 biomarker detection device for the diagnosis of } \\
\text { Alzheimer's disease, method of application of said device, } \\
\text { use of said device for Alzheimer's disease diagnosis, ELISA } \\
\text { method of application for Alzheimer's disease diagnosis }\end{array}$ & G01N 33/68 & Nurse' \\
\hline $\begin{array}{l}\text { BR } 102015 \\
0240937\end{array}$ & 9/18/2015 & $\begin{array}{l}\text { Pharmaceutical composition comprising [10]-gingerol } \\
\text { and use as an antitumor and antimetastatic molecule }\end{array}$ & A61K 9/51 & Nurse' \\
\hline $\begin{array}{l}\text { BR } 102014 \\
0244786\end{array}$ & 9/30/2014 & $\begin{array}{l}\text { Process of obtaining ruthenium compounds with } \\
\text { bioligants, ruthenium compounds with bioligants and } \\
\text { their use }\end{array}$ & C01G 55/00 & Nurse' \\
\hline $\begin{array}{l}\text { BR1020180120 } \\
\text { Not found }\end{array}$ & $6 / 13 / 2018$ & Handmade model for intestinal ostomy training & Not found & $\begin{array}{l}\text { Nurse "Ongoing } \\
\text { professional master's } \\
\text { course in Surgery and } \\
\text { Experimental Research }\end{array}$ \\
\hline $\begin{array}{l}\text { BR5120190003519 } \\
\text { Not found }\end{array}$ & $12 / 20 / 2018$ & SafeCare: Patient safety management & Not found & $\begin{array}{l}\text { Nurse " Ongoing } \\
\text { professional master's } \\
\text { course in Surgery and } \\
\text { Experimental Research }\end{array}$ \\
\hline $\begin{array}{l}\text { BR512018051587-8 } \\
\quad \text { Not found }\end{array}$ & $7 / 17 / 2017$ & CuidarTech Foot Exam, Registration institution & Not found & Nurse "II \\
\hline $\begin{array}{l}850170154422 \\
\text { Not found }\end{array}$ & Not found & CuidarTech & Not found & Nurse III \\
\hline
\end{tabular}

Chart 2 - Patent synopsis, registered in the Lattes Curriculum with their respective request records, filing date, patent title, international patent classification, and the inventor's area of expertise. Brazil 2004-2019.

Source: Lattes Platform, 2019. 
and appreciation regarding applied research, and applied research for use in stricto sensu courses, especially those whose origin lies in the professional modality ${ }^{(13)}$.

It must be understood, however, that the agreements to register a patent, mainly here in Brazil, involve long negotiation processes involving the researcher, the affiliation institution, and the affiliated and associated company. There are multiple negotiations that involve complex and tedious procedures for protection purposes, for which the research institution must have trained specialists to solve the procedures and propose the subsequent marketing action. Also according to Cuestas ${ }^{(14)}$, patent registration only works if its use implies direct use. Although, under this same view, the quality criteria of a graduate course should not be judged by the number of registered patents, since the procedures between the patent's registration and the registration of use are subject to complicated long-range processes, the result of which is determined by a large number of variables.

Thus, although we are considered a developing country, it is believed that research originating from stricto sensu graduate programs, especially those in the field of Nursing, is capable of contributing to our technological growth both nationally and internationally. In a period of eighteen years of uninterrupted actions, the professional master's programs in nursing have effectively contributed to reduce the distance that separates the Academy and the world of work, making it possible, through numerous technological products, to improve in the most varied areas where nursing applies ${ }^{(14)}$.

\section{FINAL CONSIDERATIONS}

From the above, it can be analyzed that the number of patent registrations has no significant relationship with the prelude and the growth of the stricto sensu programs in the professional master's in nursing modality. However, scholars in the field believe that this modality is on a clear path of ascension, restructuring of its concentration fields and lines of research/performance, which in a short period of time may contribute to the increment of new research and, in turn, in products or processes subject to patent registration in the nursing field.

In fact, it is believed that nurses, when entering the professional master's degree course, have no idea of the importance of patenting their final product, and their concern is focused on the development and implementation of their creation, the result of the development of their dissertation, to be employed at the institution to which it is linked. This production adds value to the nursing assistance itself, to the organization of the public or private network unit, to patients and family members, to the health professional teams, and the technical production of postgraduate studies, especially in this modality, although the low commitment in registering patents, even by institutions that are favored by these products, is noticed.

In this sense, this study brings contributions related to teaching, research and assistance, as it presents the incipient results in the production of patents that give visibility to the work developed by nurses, data that are also restricted in the area of health as a whole. One of the contributions may come from the implementation of actions that help professionals focus on the registration of their inventions and, therefore, there is a need to encourage discussions regarding the investment to be made to register the productions that may emerge through course offers and/or compulsory/optional subjects, which offer specific knowledge in the area of intellectual production, both for professors who work in professional master's degree courses and for students who enter these courses. This appropriated knowledge points to the identification of products/processes that have the potential to generate innovations in the healthcare market.

Throughout its trajectory, nursing has always been, and increasingly becomes. a promising field in terms of offering safe and quality care, and the creation of processes/products has this focus. These creations, in their different designs, involve different health technologies and often need professionals from other fields of knowledge who help from the initial phase to the final configuration of production. It is noteworthy, therefore, that the registration of patents is a job that involves training and appropriate knowledge of the topic and the form of production. The nurses'knowledge of the theme deepens throughout the development of the professional master's degree, but concerning the way it is shaped, it can count on other professionals with specific mastery over its development.

This partnership also brings benefits to patent registration, which provides protection for one's creativity, and may be innovations that can generate wealth in a safe manner, stimulating national and international trade, contributing to the promotion of discussions in the scientific community regarding the increase in this area's productivity, stimulating new means of production in health and, improving the quality of life of society as a whole.

\section{REFERENCES}

1. Gomes ATL, Assis YMS, Ferreira LL, Bezerril MS, Chiavone FBT, Santos VEP. Technologies applied to patient safety: a bibliometric review. Rev Enferm CentroOeste Min. 2017;7:e1473. doi: https://doi.org/10.19175/recom.v7i0.1473 
2. Koerich MHAL, Vieira RHG, Silva DE, Erdmann AL, Meirelles BHS. [Brazilian technological output in the area of nursing: advances and challenges]. Rev Gaúcha Enferm. 2011;32(4):736-43. Portuguese. doi: https://doi.org/10.1590/ S1983-14472011000400014

3. Mamede W, Abbad GS. [Educational goals in a professional master degree in Public Health: assessment according Bloom's taxonomy]. Educ Pesqui. 2018;44:e169805. Portuguese. doi: https://doi.org/10.1590/ s1678-4634201710169805

4. Ministério da Educação [BR]. Portaria normativa n 389, de 23 de março de 2017. Dispõe sobre 0 mestrado e doutorado profissional no âmbito da pósgraduação stricto sensu. Diário Oficial da União 2017 mar 24 [cited 2019 Aug 25];155(58 Seção 1):61. Available from: https://capes.gov.br/images/stories/ download/legislacao/24032017-PORTARIA-No-389-DE-23-DE-MARCODE-2017.pdf

5. Ferreira $R$, Tavares C. Publicações de enfermeiros no mestrado profissional de enfermagem: revisão integrativa. Rev Pesqui: Cuidado Fundam on line. 2018 [cited 2019 Aug 25];10(esp):88-91. Available from: http://www.seer.unirio.br/ index.php/cuidadofundamental/article/view/7611/6596

6. Camargo MG. A importância da criatividade como fator de inovação para as corporações e o design. Blucher Design Proceed. 2014 [cited 2019 Aug 25]:1(4) Availablefrom:http://pdf.blucher.com.br.s3-sa-east-1.amazonaws.com/design proceedings/11ped/00720.pdf

7. Instituto Nacional da Propriedade Industrial (BR). Diretoria de Patentes. Diretriz de exame de patentes de modelo de utilidade. Rio de Janeiro: INPI; 2012 [cited 2019 Aug 25]. Available from: https://www.gov.br/inpi/pt-br/servicos/ patentes/pagina_consultas-publicas/arquivos/diretriz_de_mu_versao_2_ original.pdf/
8. Instituto Nacional da Propriedade Industrial (BR) [Internet]. Rio de Janeiro: INPI; c2019 [cited 2019 Aug 25]. Consulta à Base de Dados do INPI; [about 1 screen]. Available from: https://gru.inpi.gov.br/pePI/jsp/patentes/PatenteSearchBasico. jsp

9. Andrade SR, Schmitt MD, Storck BC, Piccoli T, Ruoff AB. Documentary analysis in nursing theses: data collection techniques and research methods. Cogitare Enferm. 2018;23(1):e53598. doi: https://doi.org/10.5380/ce.v23i1.53598

10. lattes.cnpq.br/ [Internet]. Brasília, DF: CNPq; c2019 [cited 2019 Aug 25]. Available from: http://lattes.cnpq.br/

11. Santos MIP, Silveira MF, Oliveira EA, Martelli DRB, Dias VO, Veríssimo FM, et al. Evaluation of scientific production, patents and human resources training in the Brazilian nursing. Rev Bras Enferm. 2015;68(5):846-54. doi: https://doi. org/10.1590/0034-7167.2015680512i

12. Coordenação de Aperfeiçoamento de Pessoal de Nível Superior (BR). Relatório de avaliação 2013-2016: quadrienal 2017. Brasília, DF: Capes; 2017 [cited 2019 Aug 25]. Available from; https://docs.google.com/ viewer? $\mathrm{a}=\mathrm{v} \&$ pid $=$ sites\&srcid $=$ Y2FwZXMuZ292LmJyfGF2YWxpYWNhby1xd WFkcmllbmFsfGd40jlyNzczOTY5MTgxNDQzY2M

13. Academia Brasileira de Ciências. Considerações sobre o processo de avaliação da pós-graduação da CAPES: contribuição da Academia Brasileira de Ciências. Rio de Janeiro: ABC; 2018 [cited 2019 Aug 25]. Available from: http://abc.org.br/ IMG/pdf/sugestoes_capes.pdf

14. Cuestas, E. La investigación académica y su relación com empresas, industrias y actividades productivas: un vínculo que debe consolidarse. Rev Hospital Materno Infantil Ramón Sardá. 2011 [cited 2019 Aug 25];30(2):51-5. Available from: http://www.redalyc.org/articulo.oa?id=91218911002

\section{- Corresponding author:}

Claudio José de Souza

E-mail: claudioenfo@gmail.com

\section{Associate editor:}

Cecília Helena Glanzner 